\title{
PENGARUH PEMBERIAN JAMBU BIJI MERAH MERAH \\ TERHADAP KADAR HEMOGLOBIN PADA AKTIFITAS FISIK MAKSIMAL MAHASISWA JURUSAN ILMU KEOLAHRAGAAN 2016
}

\author{
Oleh \\ Mesnan ${ }^{1}$, Herpina N Simanullang ${ }^{1}$ \\ ${ }^{I}$ Fakutas Imu Keolahragaan, Universitas Negeri Medan \\ Email : herpina.simanullang@gmail.com
}

\begin{abstract}
Abstrak
Tujuan dari penelitian ini adalah untuk mengetahui pengaruh pemberian jambu biji merah merah terhadap kadar hemoglobin pada aktifitas fisik maksimal mahasiswa jurusan ilmu keolahragaan stambuk 2016. Penelitian dilakukan di Stadion Universitas Negeri Medan. Penelitian ini menggunakan penelitian eksperimen, dengan metode Two Groups Pretest-Posttest Design. Sampel penelitian Mahasiswa Ilmu Keolahragaan Stambuk 2016 sebanyak 12 orang. Aktifitas fisik maksimal dilakukan dengan bleeptest. Hemoglobin di ukur dengan perbadingan pemberian jambu biji merah dengan air mineral dan pemeriksaan kadar Hemoglobin dilakukan di awal dan/diakhir perlakuan.Teknik analisis data pada penelitian ini menggunakan uji t. Hasil penelitian menunjukkan terjadi penurunan kadar rata-rata Hemoglobin pada jambu biji merah $=9,917 \mathrm{~g} / \mathrm{dl}$ (pretest) menjadi $=8,45 \mathrm{~g} / \mathrm{dl}$ (post test) dan pada air mineral =9,7667 $\mathrm{g} / \mathrm{dl}$ (pretest) menjadi $=9,2 \mathrm{~g} / \mathrm{dl}$ (posttest) dengan nilai bleeptest pada kelompok ekperimen 40,1667 dan kelompok kontrol 42,633. Hasil uji analisis diperoleh nilai $p=0,99$ pada jambu biji merah, $p=0,118$ pada air mineral dan $p=0,475$ pada bleeptest yang menunjukkan tidak ada perbedaan yang bermakna ( Tidak signifikan) kadar Hemoglobin pretest dan post test dan bleeptest jambu biji merah dengan air mineral. Penelitian ini menyimpulkan bahwa jambu biji merah tidak mempengaruhi kadar Hemoglobin pada Mahasiswa Stambuk 2016.
\end{abstract}

Kata Kunci: Hemoglobin, Jambu Biji Merah

\section{A. PENDAHULUAN}

Aktifitas fisik berat dapat meningkatkan komsumsi oksigen 100-200 kali lipat karena terjadinya peningkatan metabolisme di dalam tubuh. Peningkatan penggunaan oksigen terutama oleh otot-otot yang berkontraksi, menyebabkan terjadinya peningkatan kebocoran elektron dari mitokondria yang akan menjadi SOR (Senyawa Oksigen Reaktif) (Clarkson, 2000.)

Umumnya 2-5\% dari oksigen yang digunakan dalam proses metabolisme di dalam tubuh akan menjadi ion superoksid sehingga saat latihan fisik maksimal terjadi peningkatan produksi radikal bebas. Pada saat produksi radikal bebas melebihi 
antioksidan pertahanan seluler maka dapat terjadinya stres oksidatif, dimana satu faktor penyebabnya adalah akibat latihan fisik (Chevion, 2003).

Menurut Sauza (2006), selama latihan fisik maksimal, konsumsi oksigen didalam tubuh dapat meningkatkan sampai 20 kali, sedangkan konsumsi oksigen didalam serabut otot diperkirakan meningkatkan sampai 100 kali lipat. Peningkatan komsumsi oksigen inilah yang mengakibatkan terjadinya peningkatan produksi radikal bebas yang dapat menimbulkan kerusakan sel. Stres oksidatif adalah suatu keadaan dimana produksi radikal bebas melebihi antioksidan sistem pertahanan seluler, sehingga terjadinya kerusakan membran sel termasuk sel otak dan hati (Evans, 2000)

Hasil studi menunjukkan bahwa stres oksidatif adalah salah satu faktor yang bertanggung jawab terhadap kerusakan eritrosit selama dan setelah latihan fisik dan dapat menyebabkan anemia yang sering disebut "sport anemia". Akibat turunya kadar hemoglobin dan juga menyebabkan kerusakan pada jaringan otot Kerusakan jaringan otot dan darah ini diangap terlibat dalam proses kelelahan, atau ketidakmampuan untuk menghasilkan tenaga. Kerusakan akibat stres oksidatif juga dapat mengubah histokimia dan menyebabkan nyeri otot (Vina, et al., 2000).

Zhu dan Haas (1997), mengatakan bahwa penurunan $\mathrm{VO}_{2}$ max dapat terjadinya pada penderitaan anemia dengan kadar hemoglobin yang menurun dan konsekuensinya adalah menurunya kapasitas transor oksigen di dalam darah sehingga dapat mempengaruhi performance seseorang. Buah jambu biji merah diketahui mempunyai kandungan vitamin $\mathrm{C}$ lima kali lebih besar dibandingkan dengan buah jeruk, kandungan ini dapat meningkatkan kadar hemoglobin pada darah.

Kandungan vitamin $\mathrm{C}$ buah jambu biji sekitar $87 \mathrm{mg}$, dua kali lipat dari jeruk manis (49 mg/100 g), lima kali lipat dari jeruk, serta delapan kali lipat dari lemon (10,5 mg/100 g). Dibandingkan jambu air dan jambu bol, kadar vitamin C pada jambu biji jauh lebih besar, yaitu 17 kali lipat dari jambu air $(5 \mathrm{mg} / 100 \mathrm{~g})$ dan empat kali lipat dari jambu bol (22 mg/100 g). Di samping berfungsi sebagai antioksidan, vitamin C juga berfungsi menjaga dan memacu kesehatan pembuluh kapiler; mencegah anemia gizi, sariawan, gusi yang bengkak dan berdarah (penyakit skorbut); serta mencegah tanggalnya gigi. Vitamin $\mathrm{C}$ dosis tinggi dapat meningkatkan sistem kekebalan tubuh dalam melawan berbagai infeksi, sehingga tidak mudah menyebabkan sakit, seperti flu, batuk, demam, dan lain-lain. Vitamin $\mathrm{C}$ juga berperan untuk pembentukan kolagen yang 
sangat bermanfaat untuk penyembuhan luka. Ketersediaan vitamin C yang cukup dalam darah dapat mendorong ke selenium dalam menghambat sel kanker, terutama kanker paru-paru, prostat, payudara, usus besar, empedu, dan otak (Astawan et, al. 2006).

Tabel 1

Kandungan Gizi Jambu Biji Segar pada setiap 100 gram

\begin{tabular}{cc}
\hline Komposisi & Jumlah \\
\hline Kalori (energi) (kal) & 49 \\
\hline Protein (g) & 0,9 \\
\hline Karbohidrat (g) & 12,2 \\
\hline Kalsium (mg) & 14 \\
\hline forfor (mg) & 28 \\
\hline Zat besi (mg) & 1,1 \\
\hline Vitamin A (S.I) & 25 \\
\hline Vitamin B1 (mg) & $0,02 \mathrm{~g}$ \\
\hline Vitamin C (mg) & $87^{*}$ \\
\hline Air (g) & 86 \\
\hline Bagian yang dapat dimakan (\%) & 82 \\
\hline (Haryoto, 1998) & \\
\hline
\end{tabular}

Hemoglobin adalah protein yang kaya akan zat besi, memiliki afinitas (daya gabung) terhadap oksigen dan dengan oksigen itu membentuk oxihemoglobin di dalam sel darah merah. Dengan melalui fungsi ini maka oksigen dibawa dari paru-paru ke jaringan-jaringan. Hemoglobin adalah suatu molekul yang terbentuk bulat yang terdiri dari 4 sub unit. Setiap sub unit mengandung satu bagian heme yang berkunjungasi dengan suatu plopeptida. Heme adalah suatu derivate porfirin yang mengandung besi. Polipeptida itu secara kolektif disebut sebagai bagian globin dari molekul hemoglobin menurut (Suartika,W.I, 1999).

Tabel 2

Batas Kadar Hemoglobin

\begin{tabular}{lc}
\hline & Hemoglobin \\
\hline Kelompok umur & Batas nilai hemoglobin $(\mathrm{gr} / \mathrm{dl})$ \\
\hline Anak 6 bulan -6 tahun & 11,0 \\
\hline Anak 6 tahun -14 tahun & 12,0 \\
\hline Pria dewasa & 13,0 \\
\hline Ibu hamil & 11,0 \\
\hline Wanita dewasa & 12,0 \\
\hline
\end{tabular}

(Kadar hemoglobin menurut WHO, 2001)

Aktifitas fisik yang dapat meningkatkan sistem pertahanan tubuh adalah aktivitas fisik dengan intensitas rendah dan intensitas sedang, karena aktifitas pada 
tingkat ini mengacu pada program aktifitas fisik yang dirancang untuk meminimalkan pengeluaran radikal bebas. Sedangkan aktifitas fisik yang maksimal dan melelahkan dapat meningkatkan jumlah leukosit dan neutrofil baik dalam sirkulasi maupun jaringan .Aktifitas fisik selalu menimbulkan reaksi untuk menyesuaian diri berupa respon-respon dan akhirnya tubuh akan beradtasi terhadap beban yang diterima (Cooper, 2000).

Berdasarkan uraian di atas maka masih banyak penelitian yang menjelaskan efek pemberian jus jambu biji merah terhadap hemoglobin. Jadi tujuan dari penelitian ini untuk melihat pengruh jus jambu biji merah terhadap kadar hemoglobin pada mahasiswa Ilmu Keolahragaan 2016 Universitas Negeri Medan.

\section{B. METODE PENELITIAN}

Jenis penelitian yang dilakukan adalah penelitian eksperimental semua dengan rancangan penelitian Randomized Control Group Preetest-Postest Design. Penelitian dilaksanakan di Stadion Universitas Negeri Medan (UNMED). Populasi pada penelitian ini adalahmahasiswa ilmu keolahrgaan berjumlah 51 orang. Sample penelitian berjumlah 12 orang dengan kriteria yaitu sebagai berikut: 1. Mahasiswa Ilmu Keolahragaan Stambuk 2016, 2.Berjenis kelamin laki-laki, 3.Bersedia menjadi sampel, 4.Tidak perokok.

Sample 12 orang dibagi dalam 2 kelompok yaitu kelompok kontrol dan ekperimen untuk di uji kadar hemoglobin. Setelah dilakukan pre test kelompok eksperimen diberikan jus jambu biji $100 \mathrm{ml}$ selama 2 minggu setelah itu lakukan post test terhadap kadar hemoglobin. Adapun bahan dan alat yang digunakan dalam penelitian ini adalah: Jus jambu biji merah, Air minum mineral, Larutan Drabkin, EDTA, Kaset, Meteran, Tape recorder/radio tape player, Keruncut, Stopwatch, Format test, Alat tulis untuk mencatat hasil.

Cara kerja prosedur penelitain yang dilakukan pada penelitian ini meliputi: Teknik pengumpulan data yang dilakukan dalam penelitian adalah dengan melakukan pengukuran kadar hemoglobin awal. Setiap sampel akan melakukan bleep test dan pengukuran dengan hemoglobin diakhirnya. Setelah data awal diperoleh lalu disusun dari nilai yang tertinggi hingga terendah, lalu dirandomized menjadi dua kelompok. Kelompok 1: diberikan pelakukan yaitu dengan memberikan jambu biji merah selama dua minggu. Kelompok 2: diberikan air mineral. Pada hari empat belas hari pemberian 
jambu biji merah, dilakukan post-test bagi kedua kelompok untuk mengetahui kadar hemoglobin Mahasiswa.

Data diolah dengan menggunakan program SPSS 20 dengan tingkat signifikan $\mathrm{p} \leq 0,05$ uji yang dilakukan dengan uji-t, yang didahului dengan uji Normalitas dengan Kolmogorov-Smornov.

\section{HASIL DAN PEMBAHASAN PENELITIAN}

\section{HASIL PENELITIAN}

Berdasarkan hasil analisis data dengan uji Normalitas (Shapiro-Wilk) p>0,05, menunjukkan dan berdistribusi "Normal" dapat dilihat pada tabel 3.

Tabel 3

Hasil Uji Normalitas Pemberian Jambu Biji Merah Terhadap Kadar Hemoglobin

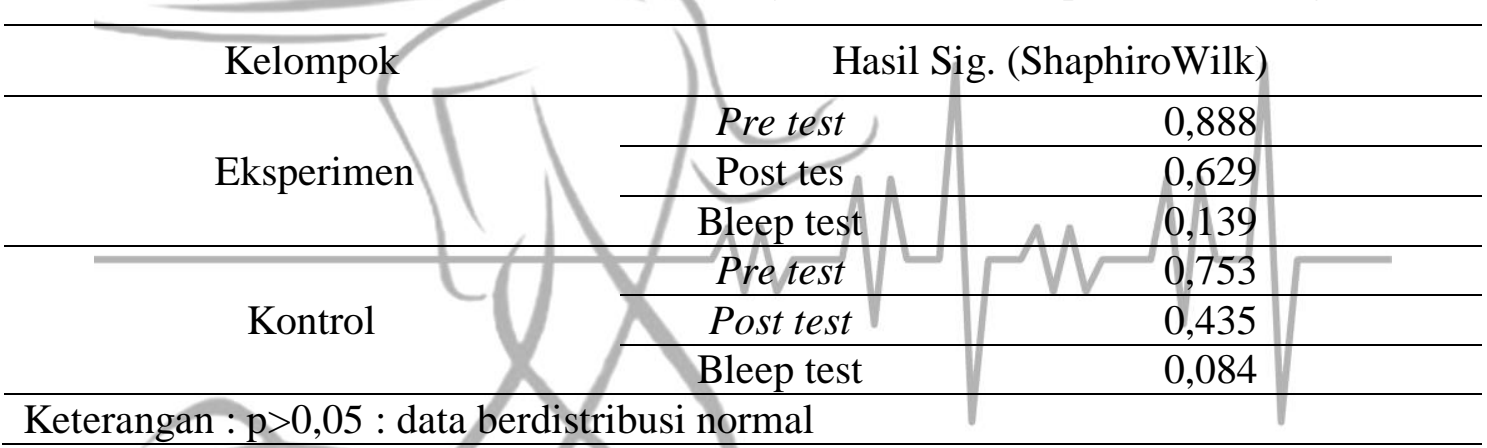

Pada tabel 3, adalah uji normalitas (Test of Normality) uji Shapiro-Wilk dapat dilihat nilai significancy untuk masing-masing kelompok semuanya $>0,05$, karena nilai probablitas $(\mathrm{P})$ lebih besar dari 0,05 maka data kedua kelompok berdistribusi "Normal".

\section{Tabel 4}

Uji t kadar hemoglobin pada kelompok kontrol dan eksperimen

\begin{tabular}{lcccc}
\hline Kelompok Eksperimen & Rerata \pm SD & Nilai $\mathrm{p}$ & Keterangan \\
\cline { 1 - 2 } Hemoglobin Pre test $(\mathrm{g} / \mathrm{dl})$ & $9,9167 \pm 1,73369$ & \multirow{2}{*}{0,99} & \multirow{2}{*}{ Tidak Signifikan } \\
\cline { 1 - 2 } Hemoglobin Post test $(\mathrm{g} / \mathrm{dl})$ & $8,45 \pm 0,94816$ & & \\
\hline uji t berpasangan & & & \\
\hline Keterangan $: \mathrm{p}<0,05$ tidak signifikan & &
\end{tabular}

Keterangan : $\mathrm{p}<0,05$ tidak signifikan

Dari tabel 4, adalah hasil uji-t berpasangan antara data pre-test dan post test kadar hemoglobin pada kelompok eksperimen dan kelompok kontrol. Dapat dilihat pada kelompok eksperimen diperoleh nilai tidak significancy $0,99(\mathrm{p}>0,05)$ yang bearti tidak ada perbedaan yang bermakna (tidak signifikan) dari nilai kadar hemoglobin antara pres-test dan post-test. 


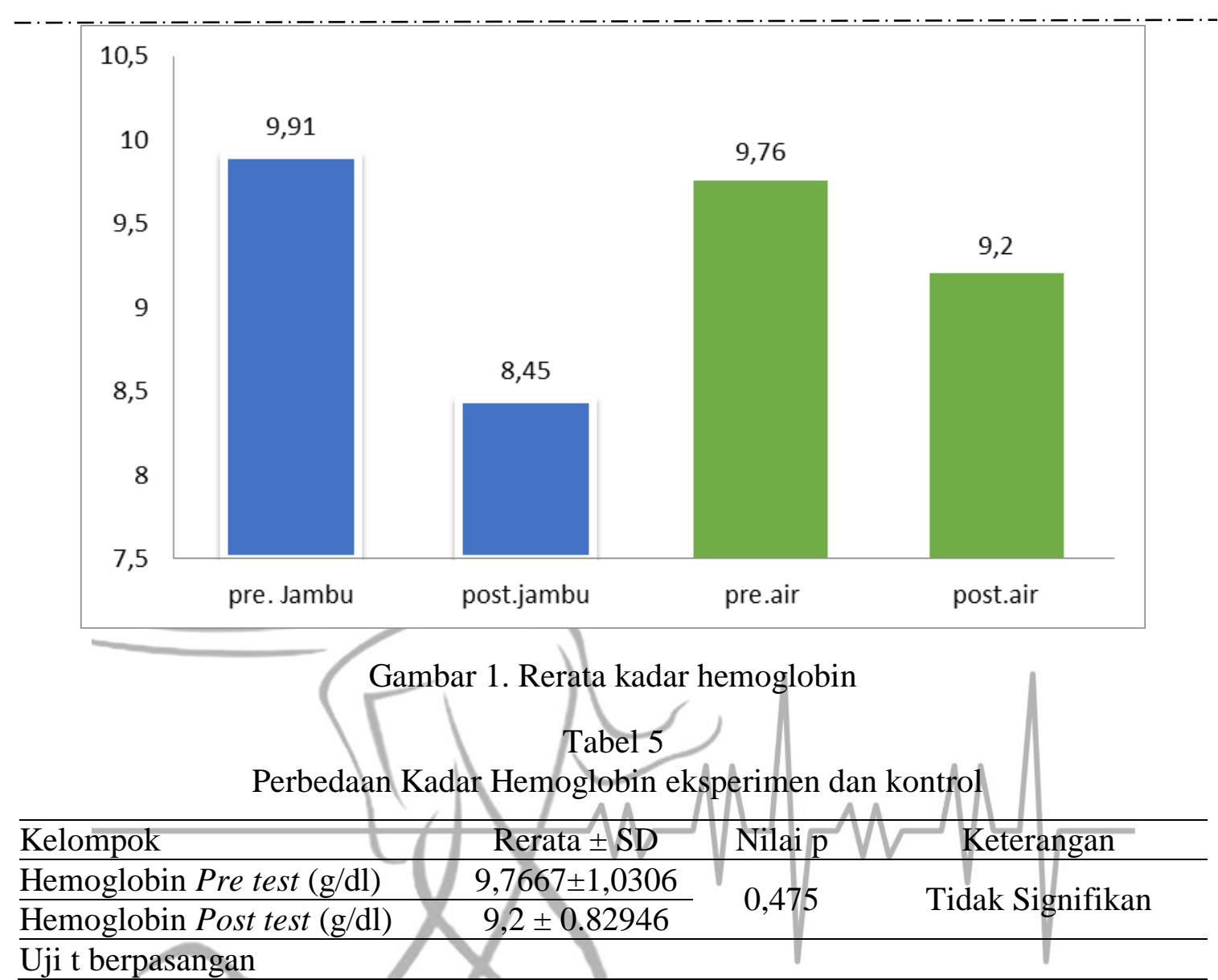

Uji t berpasangan

Keterangan: $\mathrm{p}<0,05$ tidak signifikan

Dari tabel 5, adalah hasil uji-t berpasangan antara data pre-test dan post test kadar hemoglobin pada kelomok kontrol. Dapat dilihat pada kelompok kontrol dapat dilihat nilai significancy 0,475 ( $p>0,05$ yang bearti tidak ada perbedaan yang signifikan antara pres-test dan post-test.

Pengujian hipotesis untuk hasil post test kadar hemoglobin setelah aktifitas fisik maksimal digunakan uji t tidak berpasangan untuk mengetahui perbedaan kadar hemoglobin post test antara kelompok kontrol dengan kelompok eksprimen.

Tabel 6

Perbedaan Bleep Test Kelompok Eksperimen dan Kelompok Kontrol

\begin{tabular}{lccc}
\hline Bleep Test & Rerata \pm SD & Nilai p & Keterangan \\
\cline { 1 - 2 } Bleep test Eksperimen & $40,1667 \pm 3,39627$ & \multirow{2}{*}{0,118} & \multirow{2}{*}{ Tidak Signifikan } \\
\cline { 1 - 2 } Bleep Test Kontrol & $42,6333 \pm 1,27384$ & & \\
\hline
\end{tabular}
uji t berpasangan

Keterangan : $\mathrm{p}<0,05$ tidak signifikan

Pada tabel 6, dapat dilihat menyajikan hasil analisis uji-t independent sample ttest hasil post test kadar hemoglobin. Hasil rata-rata kadar hemoglobin setelah aktivfitas 
fisik maksimal atau post test pada kelompok kontrol sebesar 40,1667 dan post test kelompok eksperimen sebesar 42,6333. Hasil uji statistik diperoleh nilai $\mathrm{p}=0,118$. Karena nilai $\mathrm{p}>0,05$ bearti dapat diambil kesimpulan bahwa terdapat perbedaan yang tidak bermakna (tidak signifikan) antara post-test kelompok eksperimen dan kelompok kontrol. Hal ini bearti tidak terdapat pengaruh yang signifikan pemberian jambu biji merah terhadap kadar hemoglobin pada aktifitas fisik maksimal.

\section{PEMBAHASAN PENELITIAN}

Berdasarkan hasil penelitian diperoleh kadar hemoglobin mahasiswa pada saat pre test di kelompok kontrol menunjukkan rata-rata kadar hemoglobin sebesar 9,7667 (g/dl) dan setelah aktifitas maksimal mengalami penurunan sebesar 9,2 (g/dl). Hasil penelitian pada kelompok kontrol (yang tidak diberikan jambu biji merah ) seluruhnya mengalami penurunan sebesar $0,5667(\mathrm{~g} / \mathrm{dl})$. Hal ini sesusai dengan hasil studi menunjukkan bahwa stres oksidatif adalah salah satu faktor yang bertanggung jawab terhadap kerusakan eritrosit selama dan setelah latihan fisik dan dapat menyebabkan anemia yang sering disebut "sport anemia" (Senturk, et al, 2001) akibat turunya kadar hemoglobin (Senturk, et al., 2005., Senturk, el al., 2004). Juga menyebabkan kerusakan pada jaringan otot (Vina, et al., 2000).

Kerusakan jaringan otot dan darah ini dianggap terlibat dalam proses kelelahan, atau ketidakmampuan untuk menghasilkan tenaga. Kerusakan akibat stres oksidatif juga dapat mengubah histokimia darah dan menyebabkan nyeri otot (Dekkers., et al 1996 ). Peningkatan radikal bebas akibat olahraga juga mempengaruhi jalur energi aerobik di dalam mitokondria, menyebabkan terjadinya kelelahan (Kendall dan Eston, 2002).

Hasil perhitungan statistik uji t berpasangan setelah aktifitas fisik maksimal pada kedua kelompok sampel diperoleh bahwa pada kelompok kontrol menunjukan bahwa ada perbedaan kadar hemoglobin yang bermakna antara berpasangan dengan nilai $\mathrm{p}$ sebesar 0,475 ( $\mathrm{p}<0,05)$. Hasil ini membuktikan bahwa sampel pada kelas kontrol yang tidak diberikan jambu biji merah mengalami penurunan kadar hemoglobin yang bearti setelah melakukan aktifitas fisik maksimal.

Hasil uji statistik berpasangan setelah aktivitas fisik maksimal pada kelompok ekperimen diperoleh ada perbedaan yang bermakna kadar hemoglobin antara berpasangan dengan nilai $\mathrm{p}$ sebesar $0,99(\mathrm{p}<0,05)$. Hasil ini membuktikan bahwa 
sampel pada kelas eksperimen yang diberikan jambu jambu biji merah mengalami penurunan kadar hemoglobin yang berarti setelah melakukan aktifitas fisik maksimal.

Berdasarkan hasil perhitungan statistik uji idependent sample t-test antara kedua kelas yaitu kelas eksperimen dengan kelas kontrol terhadap pemeriksaan kadar hemoglobin setelah melakukan aktifitas fisik maksimal menunjukkan tidak adanya pengaruh yang signitifikan. Hasil post test pada kelas eksperimen menunjukkan skor rata-rata kadar hemoglobin sebesar 9,9167 sedangkan hasil post test pada kelas kontrol menunjukkan skor rata-rata kadar hemoglobin sebesar 9,2. Dari hasil perhitungan diperoleh nilai $\mathrm{p}$ sebesar 0,7167( $\mathrm{p}>0,05)$ yang bearti Ha ditolak. Dengan demikian dapat disimpulkan bahwa secara statistik tidak terdapat pengaruh yang signifikan pemberian jambu biji merah terhadap kadar hemoglobin pada aktifitas fisik maksimal.

\section{KESIMPULAN}

Dari hasil penelitian disimpulkan pemberian jambu biji merah pada Mahasiswa Ilmu Keolahragaan selama menjalani penelitian tidak ada pengaruh pemberian jambu biji merah terhadap kadar hemoglobin pada saat melakukan aktifitas fisik maksimal.

\section{Daftar Pustaka}

Astawan, A Benardot, Abu Bakar, M.F and Hambali, Z . 2006. The Effects Of Guava (Psidium Guajava) Consumption On Total Antioxidant and Lipid Profile In Normal Male Youth. African Journal Of Ffood agriculture nutrition add development, Vol.6 No 2.

Chevion S, Moran D. S, Heled Y, Shani Y, Regrev G, Abbou B, Berenshtein E, Stadtman ER, Epstein Y. 2003. Plasma antioxidant status and cell injury after severe physical exercise, Proc.Nati.Acad.Sci.USA,Vol 100,Issue9, 5119-5123.

Clarkon, P.M. Dan Thompson, H. S. 2000. Antioxidants: what role do they play in physical activity and haelth? Am J Clin Nutr, 72,637S-46S.

Cooper, K.H. 2000. Sehat tanpa Obat: 4 Langkah Revolusi Antioksidan terjemahan dari Textbook of Antioxidant Revolution. Kaifa Bandung.

Dekkers JC, van Doornen LJ, Kemper HC. (1996). The role of antioxidant vitamins and enzymes in the prevention of exercise-induced muscle damage. Sports Med 21: 213-238.

Evans, W.J. 2000. Vitamin E, Vitamin C, And Exercise. Am J Clin Nutr, \&2, 647S$52 \mathrm{~S}$.

Haryoto. 1998. Sirup Jambu Biji, Penerbit Kanisius, Yogyakarta.

Kendall, Eston. (2002), Free radicals in the physiological control of cell function. Physiol Rev. 82;47-95.

Senturk, U. K., Gunduz, F., Kuru, O., Aktekin, M. R., Kipmen, D., Yalcin, O., BorKucukatay, M., Yesilkaya, A. \& Baskurt, O. K. (2001), Exercise-induced oxidative stress affects erythrocytes in sedentary rats but not latihan fisiktrained rats. J Appl Physiol, 91, 1999-2001. 
Senturk, U. K., Gunduz, F., Kuru, O., Kocer, G., Ozkaya, Y. G., Yesilkaya, A., Bor Kucukatay, M., Uyuklu, M., Yalcin, O. \& Baskurt, O. K. (2004), Effect of oxidant vitamin treatment on the time course of hematological and hemorheological alteration after an exhausting exercise episode in human subject. J Appl Physiol, 98, 1272-79.

Senturk, U. K., Gunduz, F., Kuru, O., Kocer, G., Ozkaya, Y. G., Yesilkaya, A., Bor Kucukatay, M., Uyuklu, M., Yalcin, O. \& Baskurt, O. K. (2005), Exerciseinduced oxidative stress leads hemolysis in sedentary but not trained humans. J Appl Physiol, 99, 1434-41.

Souza, C.F., Fernandes, L.C. and Cyrino, E.S. (2006). Production of reactive oxygen species during the aerobic and anaerobic exercise. Rev Bras Cineantropom. Desempenho Hum, Vol.8, 2006. pp. 102-109.

Suartika, W. I. 1999. Antioxidant and Oxidative stress in exercise. Society for Experimental Biology and Medicine, 283:292.

Vina J, Gomez-Cabrera MC, Lloret A, Marquez R, Minana JB, Pallardo FV.2000. Free radicals in exhaustive physical exercise: mechanism of production and protection by antioxidants. IUBMB Life, 50: 271-7.

World Health Organizution. Iron Deficiency Anemia Assessment Prevention and Control. A guide for programe maneger. 2001

Zhu, Y. I., and J. D. Haas. 1997. Iron depletion without anemia and physical performance in young women. Am.J./Clin. Nutr. 66: 334-341, 1997. 